\title{
Mixing Metaphors: Translating the Indian Medical Doctrine Tridosa in Chinese Buddhist Sources
}

\author{
C. Pierce Salguero ${ }^{1}$
}

\begin{abstract}
What constitutes success in the translation of a medical doctrine? Scholars have long thought that Chinese translators failed to understand or to transmit faithfully the Indian medical terminology they encountered within the Buddhist Tripitaka. This paper takes a closer look at the variations in the translation of the doctrine tridosa in Chinese. I argue that translation inconsistencies reflect not confusion, but a range of strategic translation decisions. While some translators prioritised closer fidelity to Sanskrit originals, most chose to emphasise the compatibility between Indian and Chinese medical thought by glossing the tridos $a$ with terms that were loaded with indigenous metaphorical connotations. In a rereading of one such passage, I show that understanding so-called errors as translation tactics allows historical analysis to move beyond a limited focus on the accuracy of translations and to instead explore the cultural resonances and social logics of translated texts in their historical context.
\end{abstract}

\section{Keywords}

Ayurveda, Chinese medicine, translation, tridoșa, Buddhist texts

As Buddhism was transmitted to China in the first millennium CE, translators faced the challenge of rendering in the Chinese language the wide range of Indian technical and scientific terminology embedded in their source texts. ${ }^{2}$

${ }^{1}$ Research for this paper was supported by fellowships from Fulbright IIE and the Charlotte W. Newcombe Foundation. This research was first presented at the Twelfth International Conference of the History of Science in East Asia (Baltimore, Md., 2008). I wish to acknowledge the participants in that session, as well as Marta Hanson, Stephen Teiser, Ven. Jianrong, Michael Stanley-Baker, Shigehisa Kuriyama, and Natalie Koehle for contributions large and small. I also especially want to thank the anonymous reviewers whose detailed corrections, comments, and critiques I have incorporated and who were most helpful in the preparation of this paper.

2 Among the most influential translations of Indian medicine in the Chinese Tripitaka are the Sutra on Buddhist Medicine (Foshuo foyi jing 佛說佛醫經, T. 793), the translation of which is attributed to Zhu Luyan 笂律炎 and Zhi Yue 支越 in the third century, and a précis of Indian doctrines included in the Sutra of Golden Light (Jin guangming jing 金光明經), translated by the Indian monk Dharmaksema between 414 and 421 (T. 663: 351c23-352a23) and again by Yijing 義淨 in 703 (T. 665: 447c19-448c06). An important collection of extracts gathered from throughout the Tripitaka is found in an encyclopedia (leishu 類書) completed by Daoshi 道世 
Translators employed a range of tactics in their efforts to come to terms with these foreign doctrines and to make Buddhist writings accessible to their contemporaries. ${ }^{3}$ Acts of translation were not only means by which Buddhist ideas could be explained to Chinese audiences, though. They simultaneously were also acts of boundary-work and identity-construction by which claims of superiority over other contemporary traditions could be made, and Buddhism's unique contributions to China could be showcased. The decision to use translation terms that underscored the foreignness of Buddhist source textsor conversely, to use vocabulary drawn from the Chinese context that emphasised Buddhism's compatibility with indigenous knowledge-were important choices that had an appreciable impact on the sangha's ability to position itself within the Chinese sociocultural landscape. ${ }^{4}$

This paper explores the translation into Chinese of an Indian medical doctrine frequently encountered in Buddhist sources: the tridosa. (Literally meaning 'three dosa'-i.e. 'three faults' or 'three defects'-this term is often misleadingly rendered in English as the 'three humours' due to perceived similarities with Greco-Roman medicine. $)^{5}$ As I show below, an analysis of how the three dos a are translated in Chinese Buddhist texts provides a window onto the broader meaning of medical knowledge in Buddhist texts, and brings to light the subtle ways in which historical translators enacted macro-level strategies at the level of the individual Chinese character.

in 668 entitled Forest of Gems in the Garden of the Dharma (Fayuan zhulin 法苑珠林, T. 2122: 984a19-989c02). (All citations of Buddhist texts in this paper refer to the digital edition of the Taishō Tripitaka available from CBETA.) For general discussions of medical doctrine and healing practices in Buddhist writings, see Demiéville 1937 (English trans. 1985); Obinata 1965; Fukunaga 1972, 1990; Mitra 1985; Birnbaum 1989a, 1989b; Nihonyanagi 1994; Zysk 2000; Deshpande 1999, 2000, 2003-04, 2008; Chen 2002, 2005a, 2005b, 2005c, 2006a, 2006b, 2007; Strickmann 2002; Mazars 2008.

3 Throughout this paper, I am using the term 'translator' loosely, as most Chinese Buddhist translations were the product of committees that could be made up of dozens or hundreds of individuals. Although it was the head of the translation committee whose name was attached to the text, this individual may not have been personally responsible for the decisions at the level of detail I discuss in this paper. For general discussions of Chinese Buddhist translation, see Boucher 1996; Cheung 2006; Nattier 2008; and the 2008 special issue of Journal of the International Association of Buddhist Studies 32 (1-2).

${ }^{4}$ I have discussed some of the broader cultural and social contexts of Indo-Sinitic medical exchange in Salguero 2009, 2010. I am currently in the finishing stages of preparing a monograph on this subject that will contain many more examples than the doctrine of tridosa discussed here.

5 See Scharfe 1999, pp. 612, 614. 


\section{The tridosa in Buddhist texts}

Before discussing the translation of the tridosa, I will first give a brief overview of the usage of this doctrine in Chinese Buddhist sources more generally. Because I am interested in making some observations about the translation corpus as a whole, the bulk of this paper will discuss the texts in the aggregate. ${ }^{6}$ Toward the end of the paper, I will pick out one specific example of a translation of the three defects, and discuss it in more detail.

Chinese Buddhist texts share with classical Indian medical writings the notion that one of the principal causes of human illness is the fluctuation of the 'Great Elements' (Skt./Pāli mahäbhūta or dhātu; i.e., Earth, Water, Fire, and Wind) that make up the body and the whole physical world. The 'internal' Elements within the body are in perpetual flux as they interact with the 'external' Elements in the world outside. Ailments arise when the internal Elements become excessive, depleted, imbalanced, mutually conflicted, or 'coarse' (Skt. karkaśa; Pāli khara; Ch. cuse 鹿涉). Most commonly, such situations occur due to shifts in the seasons, the influence of environment, improper regimen, the unwise consumption of foods, or the predominance of negative mental or emotional states. Though most Chinese Buddhist texts focus on the Elements themselves, a significant percentage hold that imbalanced Elements will manifest as Wind (Skt./Pāli vāta), Bile (Skt./Pāli pitta), and Phlegm (Skt. śleșman or kapha; Pāli semha). These are complex terms that can refer both to sets of symptoms subjectively experienced by the patient (e.g., agitation, burning, and congestion), as well as to the concrete substances that manifest in a sick human body (e.g., gas, vomit, and mucosal excretions).

The Indian understanding of these three defects developed in religious and medical texts from the last few centuries BCE through the first millennium CE. ${ }^{7}$ While Wind, Bile, and Phlegm appear among other pathological factors

\footnotetext{
${ }^{6}$ I am not a scholar of Indic languages, and therefore would not be qualified to present a comprehensive side-by-side analysis of Chinese, Pāli, Sanskrit, and Tibetan references to the tridosa. This article focuses strictly on the Chinese translations. The study of a monolingual translation corpus, not unusual in translation studies, is intended to focus squarely on the reception of translated texts in the target language and cultural environment. This paper operates from the premise that a translator's understanding of the source text, his choices for or against certain types of equivalence, and his strategy for restructuring the text in the new culturallinguistic context - in fact, even the initial decision of what text or texts to translate-are all products of his embeddedness in the social, intellectual, political, and economic climate of the target culture. I believe this approach is especially apropos in the case of Chinese Buddhist translations, as even when there are comparable texts available in other languages, these almost always represent different recensions than the texts used by the Chinese translators, and therefore are not truly source texts in the strict sense.

7 Scharfe 1999. See also Meulenbeld 1991, 1992, 2009.
} 
in the Pāli sources written in first century BCE Sri Lanka, they are not explicitly identified in these texts as doșa (Pāli dosa). Nevertheless, in the Ayurvedic medical corpus composed in subsequent centuries, mostly in northern India, the three are eventually called $d o s a$ and are given a preeminent role in etiology. In the earliest Ayurvedic writings, such as the Carakasambitä (compiled by the third century CE), the term dosa seems to have originally referred to an abnormality of Wind, Bile, and Phlegm that needed to be quelled or removed in order to return to health. By the time of the compilation of the Astāingasamgraha and Astängahrdaya (by the seventh century CE), however, the dosa had come to denote permanent features of the body that needed to be kept in balance in order to prevent disease.

Given these fluctuations in the Indian understanding, it is not surprising that Chinese Buddhist texts on medicine translated over the same timeframe contain a range of positions on the role of the three defects in pathogenesis. Chinese texts most commonly refer to Wind, Bile, and Phlegm as bing 病, a character that means both 'illness' and 'defect', thus capturing the core meanings of the Sanskrit word $d o s a .{ }^{8}$ Generally speaking, the defects of Wind, Bile, and Phlegm are blamed on disturbances of the internal Wind, Fire, and Water Elements respectively. However, the Chinese Buddhist texts depart from secular Indian medicine in that they frequently augment the traditional three dosa with a fourth major affliction, the 'Combination Dosa' (Skt. sannipāta; Pāli sānnipātikāni; Ch. dengfenbing 等分病, zongjibing 總集病, zabing 雜病, etc.), referring to the simultaneous arising of the other three. Texts that recognise this fourth affliction as a major cause of disease conventionally state that there are 404 ailments that plague humanity, 101 caused by each of the three dosa and 101 by their combination. ${ }^{10}$

Regardless of the reasons for their arising, Chinese Buddhist texts often assert that the dosa are treatable with readily available foodstuffs. While there is no consensus from text to text on what the antidotes are for each dosa, the items mentioned are most often drawn from the five basic medicines listed in the monastic disciplinary codes: ghee, butter, oil, honey, and sugar. ${ }^{11}$ Another therapy for the dosa is the administration of foods, drinks, and medicines with particular qualities of taste. The Six Flavors (Skt. sadrasa; Ch. liuwei 六味)

\footnotetext{
${ }^{8}$ Other terms used include various permutations of 'affliction' (buan 患), 'internal calamity' (nei zaihuan 內災患), and 'poison' ( $d u$ 毒).

${ }^{9}$ Demiéville 1985, pp. 71-3. Some texts on Indian medicine, such as the Bower Manuscript, consider blood as a fourth dosa or closely analogous substance (Meulenbeld 1991; Scharfe 1999, p. 616), although the majority holds that there are three.

${ }^{10}$ A competing four-fold division in some Buddhist texts states that there are 101 ailments for each Element (Demiéville 1985, p. 72).

${ }^{11}$ Demiéville 1985, pp. 69-71. I discuss one such example in the last section of this paper.
} 
from the Ayurvedic tradition are Sweet, Sour, Salty, Astringent, Bitter, and Pungent, although Buddhist sources often differ in terms of the number of Flavors as well as the qualities of taste themselves. ${ }^{12}$

Such advice on regimen notwithstanding, for the Buddhist adept, ingesting medicines or specialised foods is often held to be unnecessary-at best, it is the option of last resort. The balance of Elements can instead be managed and the arising of the dosa avoided altogether through maintaining proper diet and regimen, as well as through therapeutic meditations such as the Four Element 'absorption meditations' (Sk./Pāli samädhi; Ch. sanmei 三昧). ${ }^{13}$ The practitioner who is adept at adjusting his or her regimen and practicing the proper meditations is able to prevent the diseases that arise due to the shifts in the seasons and other fluctuations, thus maintaining health without resorting to outside assistance or medical expertise. Within the Mahāyāna tradition, however, even these measures are temporary expedients, as the ultimate prevention and cure of all illnesses comes with the realization of the Emptiness of the physical body and the illusory nature of disease. Attainment of such wisdom causes all diseases to fall away and grants the adept mastery over the body-and indeed over the entire phenomenal world. ${ }^{14}$

\section{The problem of translation equivalence}

Unlike many other types of Indian knowledge, the lexicon for translating Indian medical terms into Chinese was never fully standardised. Important medical doctrines consequently are treated unevenly in the Chinese Tripitaka,

\footnotetext{
12 For example, compare the contradictory explanations in both Chinese recensions of the Sutra of Golden Light (T. 663: 352a12-15; T. 665: 448a21-24), as well as Kumārajīva’s (344-413) translation of the Mahāprajñāpāramitā-śāstra (Da zhidu lun 大智度論; T. 1509: 60a16-21).

13 Proper diet and regimen are discussed in the Sutra on Buddhist Medicine and the Sutra of Golden Light. The therapeutic applications of the Four Element samädhi are detailed in the Secret Essentials for Treating the Maladies of Meditation (Zhi chanbing miyao fa 治禪病祕要法, T. 620), the translation of which is attributed to Juqu Jingsheng 沮渠京聲 455. In such meditations, the mind becomes fully immersed in the contemplation of one of the Elements to the extent that it influences the body. This might be turned to medical purposes when, for instance, a meditator practices visualizations of a cooling Water nature in order to decrease the amount of Fire in the body and thus ward off diseases associated with this Element (see, e.g., T. 620: 338c12-339a04). Other techniques are introduced in the chapters on therapeutic meditation in two meditation manuals attributed to Zhiyi 智顗 (authored 575-585) (T. 1911: 106a19-111c21; T. 1915: 471b02-472b13).

${ }^{14}$ The locus classicus for this doctrine is the fifth chapter of the Vimalakirti Sutra, entitled 'Mañjuśrī Inquires about the Illness' (T. 475: 544a25-546a02; English translation in Watson 1997, pp. 64-74).
} 
with different translators using divergent Chinese characters. As with most medical terminology, there is little consensus from text to text on how to translate the three main afflictions of humankind. Though the translation of the Wind defect consistently involves the Chinese character feng 風, also meaning 'wind', the options utilised by translators for the other two terms range further afield, apparently confusing or conflating agents of disease, disease categories, anatomical structures, and physiological substances. This disarray has been considered to be evidence of the translators' imprecision by some scholars, and has been cited as an indication that Indian medicine was fundamentally misunderstood or misrepresented in China. ${ }^{15}$

Of course, scholars who regularly work with the Sino-Japanese Tripitaka are well aware that there are errors in Buddhist translations. However, the wholly negative assessment of the Chinese reception of Indian medical doctrine seems to be based on the assumptions both that the source materials were consistent in their presentation of the three defects, and that Chinese translators must have adhered to only the most narrow and literal translation of Sanskrit terminology if their efforts are to be determined successful. The source texts Chinese translators dealt with, written over spans of centuries and originating in a variety of Buddhist languages, are highly unlikely to have been uniform in their presentation of the tridosa. Even more fundamental for the purposes of this paper, however, is the second question: what constitutes 'success' in the translation of a medical doctrine?

Translation theorists have long understood that perfect one-to-one equivalence between verbal expressions in different languages is a logical abstraction. ${ }^{16}$ Most scholars of translation, if they acknowledge any possibility of equivalence at all, insist that it is not something inherent in the languages, but the product of an individual translator's active negotiation and compromise between two different systems of meaning. Moreover, they understand this process of negotiation to be inseparable from the specific social context and concrete historical moment in which the translational acts take place. ${ }^{17}$ Taking this approach to translation would involve moving away from a sole focus on judging the so-called 'accuracy' of Chinese translators' output, to instead investigating the social and cultural logics that influenced how and why they dealt with Indian doctrines in particular ways.

15 Demiéville 1985, p. 67; Unschuld 2010, pp. 141-2 (cf. Unschuld 1979).

16 See, e.g., Jakobson 2004, p. 139.

${ }^{17}$ Studies of translation in this vein can be found under the rubrics of 'polysystem theory', 'descriptive translation studies', 'integrated translation studies', and 'the sociology of translation'. The relevant literature is immense, but highlights include Even-Zohar 2004, 1990, 1997; Lefevere 1992; Toury 1995; Snell-Hornby 1995; Pym et al. 2006. 
This type of analysis begins with the premise that translators of Chinese Buddhism were not haphazard in their work. In fact, we know that the major translators of the medieval period were well cognizant of the challenges of translation equivalence, as they continually reflected upon this issue and discussed their methods and goals. Generally speaking, debates between translators hinged on the tension between what were known as 'unhewn' (zhi 質) and 'refined' (wen 文) translation tactics. ${ }^{18}$ This distinction is reminiscent of the differentiation between 'word-for-word' and 'sense-for-sense' translation in European discourses on translation going back as far as Cicero (first century BCE) and St. Jerome (fourth century CE), or more recently, between 'formal' and 'dynamic' equivalence as used in modern translation studies. ${ }^{19}$

Throughout the medieval period, eminent Buddhists such as Dao'an 道安 (312/314-385) and Xuanzang 玄牀 (602-664) attempted to establish norms that would govern translation practices. ${ }^{20}$ Such rules of thumb may have sounded attractive in the abstract; however, in practice, translators were flexible and practical, tailoring their translations for specific contexts and audiences. Many were quite willing to juxtapose foreignizing and domesticating language, utilizing multiple translation tactics within the same text in order to enhance understanding or to pursue particular rhetorical strategies. ${ }^{21}$ Translators sometimes even purposefully used different characters in translating successive iterations of the same phrase within a single text or across texts in order to give a better sense of the full scope and connotation of the original. ${ }^{22}$ While prevailing norms certainly had an impact on the practice of translation, individual translators continued to employ and advocate their own favorite approaches throughout the medieval period, utilising the entire spectrum of translation options - from close adherence to the Indian originals, to freely rendered approximations that captured the spirit but not the letter of the originals, and everything in between.

Between the poles of unhewn and refined translation, there were three basic tactics available to deal with any given foreign term. First, it could be transliterated in order to minimise uncertainty about the original word. This practice, which was advocated most famously by Xuanzang, consisted of

18 Cheung 2006, pp. 10-3.

19 On this dichotomy in the European tradition, see Friedrich 1992.

20 On translation norms, see Toury 1995, pp. 53-69.

${ }^{21}$ See, e.g., Boucher 2008, p. 91, on Dharmarakșa’s propensity to translate proper names into Chinese as part of a strategy to 'market [his] otherwise strangely hybrid, semiliterary productions'.

${ }^{22}$ Table 1 below contains some instances where the defects were translated in different ways within the same text, perhaps for this very reason. 
approximating Sanskrit pronunciation with a nonsensical string of specialized Chinese characters, such as when the word dharāni was written as tuoluoni 羅尼. ${ }^{23}$ Secondly, the translator could render an Indian term with a semantically precise translation. This occurred, for example, when the same term dharanni was translated as zongchi 總持, or 'encompassing grasp', capturing the word's literal meaning of 'to hold' or 'to grasp' in Sanskrit. ${ }^{24}$ In many cases, these formally equivalent translation terms utilized an existing Chinese word, often requiring a minor shift or extension in its semantic field. In other instances, the translator's root-for-root translation resulted in the creation of a neologism.

A third approach to translation, however, involved glossing Buddhist terms with dynamic equivalents drawn from the existing Chinese religiomedical vocabulary. This occurred, for example, in cases where dharānī was translated as zhou 咒 ('spell') or shenzhou 神咒 ('spirit-spell' or 'magic spell'). As these terms were already infused with connotations derived from the indigenous Chinese experience of the spirit-world, they can be understood as 'metaphorical equivalents' ${ }^{25}$ As the translator substituted the Chinese word for the Sanskrit, he brought together a constellation of Indian doctrines, practices, and associations implicit in the foreign term dharān $\bar{\imath}$ with the similarly extensive autochthonous resonances of zhou. As with all successful metaphors, the bringing together of these two conceptual systems enriched both sides of the equation. ${ }^{26}$ Once the equivalence between dharāni and zhou was established, Buddhists were able to tap into the indigenous Chinese repertoire when explaining the practices associated with dharāni, while Daoist priests and other ritual specialists using zhou also gained a number of new ideas, techniques, and rationales from the Indian context as well. ${ }^{27}$

${ }^{23}$ For Xuanzang's position on transliteration, see Cheung 2006, pp. 156-9. For an analysis of his practice of transliteration, see Chen 2004.

${ }_{24}$ See discussion in Copp 2008.

25 On metaphorical equivalence, see Stewart 2001; Orzech 2002, 2002-03. Metaphorical equivalence is not to be confused with the more formalised and far less common exegetical system of 'matching concepts' (geyi 格義). While geyi is indeed an example of metaphorical equivalence, the vast majority of metaphorical equivalence should not be considered geyi (see Mair 2010).

${ }^{26}$ On the reciprocal nature of metaphors, see Black 1954, 1993.

${ }_{27}$ On the syncretism of Buddhist and Daoist spellcraft and other magical medicine, see Strickmann 2002; Mollier 2008. 


\section{Translation errors or translation tactics?}

Having introduced the range of tactics utilised by translators during the medieval period, we can now turn to an examination of the Chinese characters they used to translate the tridosa. TABLE I below contains a list of translation terms used to gloss the three defects (and, often, their combination) between the second and tenth centuries, organized by the putative date of the translation. I do not presume that this is a complete accounting of all references to the doctrine in medieval Chinese Buddhist literature, but it is a large enough and diverse enough sample to serve as a basis for some general observations.

The first thing about this table that commands our attention is the stability of the translation of the Wind dos a versus the variability of the other two over time. Using feng 風 (Wind) or fengbing 風病 (Wind defect) clearly was seen as a favorable solution for dealing with this one dosa, while translators appear to have been much more flexible in their translation choices for the other two, especially for Phlegm. I argue that the Chinese term feng was such a successful translation for the Wind defect because it was both a semantically precise way to render the foreign word, as well as a powerful metaphorical equivalent that tapped into a wealth of resonances from Chinese medicine and demonology, where feng had long been considered among the major causes of disease. ${ }^{28} \mathrm{On}$ the other hand, literal or roughly literal translations of the other two dosasuch as Gallbladder (dan 膽) for the Bile defect, or those translations involving the characters for Phlegm ( $\tan$ 痰) for the Phlegm defect—were attempted less frequently because they lacked such strong metaphorical resonances. ${ }^{29}$

Consequently, instead of translating the Bile and Phlegm with narrow formal equivalents, translators cast about for other terms that could be used to gloss these two defects in dynamically equivalent ways that were more metaphorically potent. From the data in the table, we can see that several shifts in translation norms took place during the period in question-specifically, the rise in the use of the character huang 黃 for Bile in the Tang dynasty, and the shift from han 寒 to leng 冷 to tan 痰 for Phlegm over the course of the medieval period..$^{30}$ Despite such fluctuations, however, the overarching strategy seems to have been to employ Chinese characters that captured the qualities of

${ }_{28}$ On pathological winds in Chinese discourse, see Kuriyama 1994; Unschuld 2003, pp. 183-98; Hsu 2007. For comparable studies of Winds in the Indian medical literature, see Zysk 1993, 2007.

29 Both Gallbladder and Phlegm are mentioned in pre-Buddhist medical texts, but these were not foundational doctrines such as feng, $q i$ 氣, and yin-yang 陰癢. On the history of these terms in Chinese medicine and their connections with Buddhist texts, see Endo et al. 1993a, 1993b.

30 See fuller discussion in Endo 1993a. 
Table 1. Chinese translations of the dosa $a^{31}$

\begin{tabular}{|c|c|c|c|c|c|}
\hline Era & Textual Reference & Wind & Bile & Phlegm & Combination \\
\hline \multirow{3}{*}{$\begin{array}{l}\text { E. Han } \\
(25-220)\end{array}$} & T. 150A: $882 \mathrm{a} 12$ & 風 & 熱 & 寒 & \multirow{3}{*}{ 雜餘病 } \\
\hline & T. 607: 235a13-14 & 風 & 熱 & 寒 & \\
\hline & T. 313: 755c13-14 & 風 & 氣 & 寒 & \\
\hline W. Jin & T. 606: $188 \mathrm{c} 07$ & 風 & 熱 & 寒 & 共和 \\
\hline \multirow[t]{2}{*}{$(265-316)$} & T. $317: 890 \mathrm{a} 18-20$ & 風 & 熱 & 寒 & \multirow{3}{*}{$\begin{array}{l}\text { 三事合會 } \\
\text { 三合之病 }\end{array}$} \\
\hline & T. $425: 8 \mathrm{~b} 03$ & 風 & 爇 & 寒 & \\
\hline \multirow{2}{*}{$\begin{array}{l}\text { E. Jin } \\
(317-420)\end{array}$} & T. 125: 604b01 & 風 & 痰 & 冷 & \\
\hline & T. 1425: 316c20-23 & 火病 & 熱病 & 水病 & \multirow[t]{2}{*}{ 雜病 } \\
\hline \multirow[t]{5}{*}{$\begin{array}{l}\text { Latter Qin } \\
(384-417)\end{array}$} & $\begin{array}{l}\text { T. 1435: 61a16, 93c25, } \\
\text { 97a13-14 }\end{array}$ & 風 & 熱 & 冷 & \\
\hline & T. 1509: 60a17-20 & 風病 & 熱病 & 冷病 & \multirow{4}{*}{$\begin{array}{l}\text { 雜 } \\
\text { 三種雜病 }\end{array}$} \\
\hline & T. 1509: 478b14-15 & 風 & 熱 & 冷 & \\
\hline & T. 1509: 590b17 & 風 & 熱 & 冷 & \\
\hline & T. $617: 297 \mathrm{c} 20$ & 風 & 熱 & 寒 & \\
\hline \multirow{2}{*}{$\begin{array}{l}\text { Liu Song } \\
(420-479)\end{array}$} & T. $375: 755 b 16$ & 風 & 熱 & 水 & \multirow[b]{2}{*}{ 等分 } \\
\hline & T. 99: 252c21-23 & 風 & 痰 & $\begin{array}{l}\text { 唌唾 } \\
\text { [var. 涎唾] }\end{array}$ & \\
\hline \multirow{5}{*}{$\begin{array}{l}\text { N. Liang } \\
(441-442)\end{array}$} & Т. 663: 351c26 & 風 & 熱 & 水過肺 & 等分 \\
\hline & T. 633: 352a09-11 & 風病 & 熱病 & 肺病 & \multirow{3}{*}{ 等分病 } \\
\hline & T. 374: 511b18-19 & 風 & 熱 & 水 & \\
\hline & T. 374: 593c05-06 & 風病 & 熱病 & 冷病 & \\
\hline & T. 397: 169b24-25 & 風病 & 黃水 & 白水 & \multirow{3}{*}{$\begin{array}{l}\text { 合等病 } \\
\text { 雜病 }\end{array}$} \\
\hline \multirow{11}{*}{$\begin{array}{l}\text { N. Wei } \\
(535-556) \\
\text { Chen } \\
(557-589) \\
\text { Tang } \\
(618-907)\end{array}$} & T. 721: 41b23-24 & 風病 & 黃病 & 冷病 & \\
\hline & T. 721: 379a23 & 風 & 熱 & 冷 & \\
\hline & T. 1647: 382c21 & 風 & 膽 & 痰 & \multirow[t]{2}{*}{ 等分病 } \\
\hline & T. 1558: 56b28 & 風 & 熱 & $\begin{array}{l}\text { 淡 } \\
\text { [var. 痰] }\end{array}$ & \\
\hline & T. $1545: 363 \mathrm{~b} 08$ & 風 & 熱 & 痰 & \multirow{7}{*}{$\begin{array}{l}\text { 雜病 } \\
\text { 諸亲隹病 }\end{array}$} \\
\hline & Т. $220.331: 695 \mathrm{c} 15-17$ & 風病 & 熱病 & 痰病 & \\
\hline & T. $220.451: 277 \mathrm{c} 29$ & 風 & 熱 & 痰 & \\
\hline & T. 1563: 777a21-22 & 風 & 熱 & $\begin{array}{l}\text { 淡 } \\
\text { [var. 痰] }\end{array}$ & \\
\hline & T. 2125: 224a15-16 & 風 & 熱 & 痊 & \\
\hline & T. 1458: 571c10 & 風 & 熱 & 痰疗侌 & \\
\hline & T. 665: 447c25-26 & 風 & 黃熱 & 痰癊 & \\
\hline
\end{tabular}

${ }^{31}$ The textual citations in this table have been compiled from Endo 1993a, p. 47, which was the inspiration for this table, and to a lesser extent Demiéville 1985, pp. 69-72. I have corrected a handful of errors in the data presented in both of these sources, and have omitted their references to passages that are properly discussions of the etiology of the Four Elements as opposed to the tridosa. 
Table 1 (cont.)

\begin{tabular}{|c|c|c|c|c|c|}
\hline \multirow[t]{7}{*}{ Era } & Textual Reference & Wind & Bile & Phlegm & Combination \\
\hline & T. $1451: 257 \mathrm{~b} 25-26$ & 風病 & 黃病 & 痰癊病 & 總集病 \\
\hline & T. 310: 105b10 & & 黃 & 痰 & \\
\hline & T. 982: 416b23 & & 黃 & 痰癊 & 三集病 \\
\hline & T. 159: 321b03-04 & 風 & 熱 & 痰癊 & \\
\hline & T. 293: 711b27-29 & 風病 & 黃熱病 & 痰癊病 & 總集病 \\
\hline & Т. 1821: 184c03 & 風 & 熱 & 痰 & \\
\hline
\end{tabular}

heat associated with the Indian understanding of the Bile defect and those of cold associated with Phlegm. The most common terms used for Bile and Phlegm respectively, in fact, were simply Heat ( $r$ 熱) and Cold ( han 寒 or leng 冷), often affixed to the character bing 病.

Another pattern is that translators usually chose to gloss the foreign terms with a character or combination of characters that resonated with the native categories of Yin and Yang, which by the medieval period were well established as the foundational concepts of Chinese philosophy, cosmology, and religion, as well as medicine. Heat ( $r$ 熱), of course, was recognised in the Chinese medical classics as belonging among the most important pathogenic Yang factors. While perhaps the translations for Bile involving the color yellowsuch as Yellow (buang 黄), Yellow Fluid (buangshui 黄水), Yellow Illness (buangbing 黄病), Yellow Heat (buangre 黄熱), and Yellow Heat Illness (buangre 黄熱病)—may be referring to the hue of the biological substance itself, the color had associations in Chinese medicine with the yellowing of the skin as a result of Heat and Yang. ${ }^{32}$

Meanwhile, those terms used to translate the Phlegm dosa had wider resonances connoting Yin. Cold, whether written han 寒 or leng 冷, was associated with Yin in classical medicine, as was Water (shui 水), which several translators called upon to gloss the Phlegm defect. ${ }^{33}$ The Lungs-invoked by at least one translator when rendering Phlegm as Lung Illness (feibing 肺病) and Fluid in the Lungs (shuiguofe $i$ 水過肺) —was among the chief Yin viscera in the Chinese zangfu藏腑 system. ${ }^{34}$ Likewise, Saliva was the combination of Drool (xian 涎) originating in the Spleen and Spittle (tuo 唾) originating in the Kidneys-both also counted among the Yin viscera. ${ }^{35}$ Finally, the

\footnotetext{
32 See, e.g., Huangdi neijing suwen 黃帝內經素問 56 (Long and Long 2006, p. 680); Shanghan lun 傷寒論 (Mitchell et al. 1999, p. 215).

33 For an equation of Water and Yin, see Huangdi neijing suwen 33 (Long and Long 2006, p. 450).

34 See, e.g., Huangdi neijing suwen 4 (Long and Long 2006, p. 68).

35 See, e.g., Huangdi neijing suwen 23 (Long and Long 2006, p. 340).
} 
translators' use of the disease category yin 癊, which is comprised of the

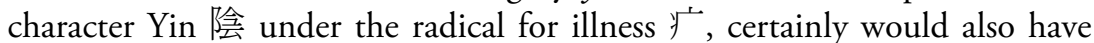
played a role in encouraging associations between this defect and the pathological influences of Yin. ${ }^{36}$

Looking at all of these metaphorical connotations in the aggregate, we must conclude that translators of Buddhist texts on the tridosa were not always primarily concerned with providing precise, formal translations of Sanskrit medical terminology. Rather, as a group, they appear to have been more interested in making connections between the Indian notions of Wind, Bile, and Phlegm and fundamental principles of Chinese medicine. I am not arguing that all Chinese Buddhists thought that the dosa were interchangeable with indigenous Chinese concepts-although some translators and exegetes certainly did make related arguments. ${ }^{37}$ However, I do intend to draw attention to how nearly all of the translators of the tridosa chose to render foreign terminology using Chinese characters that had wide webs of cultural resonances.

One reason for using these metaphorical equivalents was that doing so enabled translators to capitalise on points of qualitative similarity between Indian and Chinese doctrines, and thus to make foreign medical ideas easier to understand for their Chinese audiences. Translators knew that the Wind dosa as well as the Chinese idea of feng both related to mental and physical agitation and unease; the Bile dos $a$ and the Chinese concepts of Heat and Yang related to irritation, burning, and fever; and the Phlegm dos a and the Chinese notions of Cold and Yin related to chills, congestion, and stagnation. By translating the defects with characters that evoked these basic Chinese medical categories, translators built conceptual bridges between Indian and Chinese medical knowledge that could enhance the Chinese reader's intuitive grasp of the foreign doctrines. The fact that they did not just come right out and translate Bile and Phlegm as Yang and Yin need not surprise us, for even though they wished to tap into Chinese medical resonances, in most cases Buddhist translators no doubt also wished to preserve the unique identity of the Indian medical doctrines. Thus they walked a fine line, creatively using translation tactics to suggest continuities while also asserting difference with indigenous Chinese medical views.

36 While yin 癊 in some contexts refers to a heart condition, the Tang-dynasty Buddhist dictionary Sounds and Meanings of all the Sutras (Yiqie jing yinyi 一切經音義; T. 2128: 555c20) explains it as a type of Phlegm disorder.

${ }^{37}$ For example, Paramārtha (499-569), Zhiyi 智顗 (538-597), and Jizang 吉藏 (549-623) all produced commentaries on the Sutra of Golden Light that went out of their way to equate Indian and Chinese medical doctrine (T. 1785: 80b20-82a05; T. 1787: 171b19-172c29). 


\section{The cultural and social logics of Buddhist medical translation}

One of the chief reasons that scholars have underappreciated the ingenuity of Chinese translators in loading their translations of the tridos $a$ with indigenous metaphorical resonances is that they have approached the passages in which such references occur with the assumption that they were intended chiefly as expositions of Indian medical doctrine. The surrounding text and the broader goals of the Buddhist treatises in which they are found have not been adequately considered. In fact, analysis of these factors is vital to understanding why Buddhist texts are invoking medical terms in the first place, and can help us to recognize that how translators approached medical terms was influenced by a variety of social concerns beyond simply the portrayal of Indian doctrine.

For example, take the following passage from a Buddhist translation, which has been cited by the historian of Chinese medicine Paul Unschuld as an instance of the 'erroneous interpretation' of the dosa on the part of a Chinese translator. In this passage, which comes from an early Āgama text attributed to An Shigao 安世高 (fl. 148-170), the Buddha begins an address to the sangha gathered in the Jetavana Grove with the following words: '世間有三 大病。人身中各自有。何等為三。一為風。二為熱。三為寒。' 38

While the source text used as a basis for this translation is not extant, we can feel confident that the original lines must have read something like the following:

In this world there are three dosa that exist within every person's body. What are these three? The first is vāta; the second is pitta; the third is slesman. ${ }^{39}$

However, Unschuld argues, such an interpretation would not be the 'most obvious to an impartial Chinese reader'. Instead of the tridosa, such a reader would understand the Buddha's statement as making reference to the three familiar Chinese medical pathogens of Wind, Heat, and Cold. Interpreted in

38 T. 150A: 882a12-14; cited in Unschuld 2010, p. 142. The passage appears in the Taisho Tripitaka under the title Sutra on the Seven Points and Three Contemplations (Foshuo qichu sanguan jing 佛說七處三觀經, T. 150A), a composite text comprising several selections from the Ekôttarikâgama. The section under consideration here has a parallel in the Pāli (Anguttaranikāya III.68), but the dosa and their remedies are not mentioned in that source (see Harrison 1997: 270). For the somewhat convoluted provenance of this text, see Harrison 1997; Vetter and Harrison 1998; Nattier 2008: 52-3. Similar formulations appear elsewhere in the Chinese Tripitaka, most notably in a separate translation of the Ekôttarikâgama (T. 125: 604a28-b15) completed several centuries after An Shigao's. See also passages in the Mahäparinirvāna-sūtra ( $D a$ banniepan jing 大般涅槃經; T. 374: 511b17-23, 593c05-13; T. 375: 755b13-21), which are less similar, as well as in the Mahāsāmghika-vinaya (Mohe sengqi lü 摩訶僧祇律; T. 1425: 316c20-23) and the Mahäprajnäāpäramitā-śástra (T. 1509: 60a16-b03).

39 This is my translation, but cf. Unschuld 2010, p. 142. 
this way, says Unschuld, the Buddha's statement would likely be understood as saying:

In this world there are three grave illnesses. All appear independently in the human body. What are they? The first is [caused by] Wind; the second is [caused by] Heat; the third is [caused by] Cold. ${ }^{40}$

Unschuld is correct in drawing attention to the potential ambiguity of this passage in Chinese translation. However, the either-or decision he presents us between Indian or Chinese medical readings of the passage is not necessary. Having seen above that translators dealt with the tridosa by employing a range of metaphorical equivalents, and that such correlations tended to capitalise on qualitative similarities between Indian and Chinese medical ideas, we should instead focus on the many metaphorical resonances of the key characters in the passage in order to evaluate how they might have been understood by contemporary readers steeped in Buddhist and Chinese medical thinking. A 'thick translation', or an unpacking of the multivalency of the passage, might read thus: ${ }^{41}$

In this world there are three 大病 [major diseases, defects, faults, or afflictions] that exist within every person's body. What are these three? The first is 風 [all disorders and pathogens relating to Wind, movement, circulation, agitation, breath, and other wind-like factors]. The second is 熱 [all disorders and pathogens relating to Bile, excess Yang, Yellow, and other factors associated with heat and burning]. The third is 寒 [all disorders and pathogens relating to Phlegm, excess Yin, Cold, Water, Lungs, and other factors associated with stagnation, congestion, and retention of liquid].

Of course, when the metaphorical resonances are made explicit in this way, this becomes an unwieldy passage in English. My point is not that this is a stylistically superior (or even desirable) translation of the lines in question, but rather simply that the Chinese passage has too many layers of meaning packed into its few characters to be expressed succinctly. This far-reaching web of connotations is a quality that Mikhail Bakhtin famously called 'heteroglossia'. ${ }^{42}$ In this case, the resonances extend across multiple religious and medical discourses and involve more than one language and culture.

Why must we attend to the broader metaphorical connections between Indian and Chinese doctrines in this text? The answer is that the translator is trying to replicate not the precise word-for-word meaning of the original

\footnotetext{
40 Translated in Unschuld 2010, p. 142. I have made changes to Unschuld's capitalization to match the conventions I am following in this paper. Brackets are in the original.

41 On the principles of 'thick translation', see Appiah 1993.

42 Bakhtin 1981, p. 273.
} 
passage, but its overall sense-and to do so in language that would have been readily apprehended by his readers. When we read the context in which the three defects are introduced in the text, it becomes clear that the main point of the Buddha's statement is not to expound on Indian medical doctrine. A reading of the lines immediately following the passage just quoted reveals that the Buddha's statement is simply intended to encompass any and all diseases, bar none, in order to make a larger doctrinal point:

For these three defects, monks, there are three principal medicines. For the Wind defect, monks, there is hemp-seed oil as the principal medicine, as well as hempseed oil derivatives. For the Bile defect, there is butter as the principal medicine, as well as butter derivatives. For the Phlegm defect, there is honey as the principal medicine, as well as honey derivatives. These, monks, are the three defects and their three principal medicines.

People likewise have three [mental or spiritual] defects that arise together and persist together, according to the virtuous teachings of the Dharma. What are these three? The first is desire; the second is hatred; the third is ignorance. Monks, for these three defects, there are [also] three principal medicines. For the defect of desire, monks, there is the principal medicine of contemplation on the loathsome substances of the body. For the defect of anger there is the principal medicine of compassionate deeds. For the defect of ignorance there is the principal medicine of the contemplation of karmic causality. These, monks, are the three medicines for the three [mental or spiritual] defects.

是三大病。比丘有三大藥。風者比丘大病麻油大藥亦麻油輩。熱大病者 酪酥大藥亦如酪酥輩。寒大病者蜜大藥亦如蜜輩。是比丘三大病是三大 藥如是。

人亦有三病共生共居道德法見說。何等為三。一者欲。二者恚。三者 癡。是比丘三大病有三大藥。欲比丘大病者。惡露觀思惟大藥。恚大病 等慈行大藥。癡大病從本因緣生觀大藥。是比丘三大病者三藥。43

Understanding the context in which the tridosa are invoked is critical to understanding why the translator employs metaphorical glosses rather than narrow formal equivalents in his treatment of the dosa. The Buddha's statement to the monks presents a simple three-part typology of physical ailments. He goes on to suggest that these maladies are easily cured with commonly available foodstuffs. Then, the Buddha draws an analogy between the straightforwardness of applying these antidotes to cure all diseases and the equal ease with which basic Buddhist practices can curtail desire, hatred, and ignorancethe mental or spiritual analogues to the dosa.

What goes without saying in the text, but which would be immediately apprehended by the intended reader, is that the three antidotes for mental and spiritual defects mentioned by the Buddha (meditations to overcome

${ }^{43}$ T. 150A: 882a14-22 (my translation, but cf. Unschuld 2010, p. 143). 
self-identification with the body, compassionate deeds of meritmaking, and contemplation of karmic causes and effects) are patently Buddhist practices. Thus, at its very essence, the passage is arguing that the knowledge to effectively and easily alleviating all of humanity's ultimate sources of suffering are to be found in basic Buddhist approaches-as opposed to those associated with any other contemporary religious or medical group.

Understanding the meaning of the Buddha's statement correctly hinges on knowing that, when he mentions the tridosa in this text, his words are in fact meant to encompass any and all human diseases, because it is only in this way that he can be making the broadest claim for the efficacy of Buddhist practice in curing all mental and spiritual defects. The translator apparently decided that establishing metaphorical connections to the three indigenous categories of Wind, Heat, and Cold was advantageous for making this sense of completeness and inclusivity comprehensible to a Chinese reader.

As it turns out, this passage is not a case of translator error. Although the chosen translation terms may blur distinctions between Indian and Chinese physiology, nosology, and etiology of interest to learned physicians, this text has other work to do than medical sophistry. The tactics used here represent one translator's attempt to use indigenous Chinese metaphorical resonances to enhance his readers' comprehension of foreign material. In addition to making Indian medical doctrines accessible to a new audience, the passage also stakes a claim of superiority over other groups competing for patronage in the religiomedical marketplace. In the final analysis, it is these cultural and social logics of the translation terms, and not their medical logic, that demand our closest attention.

\section{Conclusion}

Exploration of the wider cultural and social contexts in which the transmission and reception of foreign knowledge takes place requires that scholarly analysis move beyond how close the 'fit' is between the source and target terminology. In recent decades, translation theorists have largely turned away from judging the accuracy or inaccuracy of translations (however such criteria may be conceived), and have instead concentrated on analyzing the social and cultural contexts in which certain types of equivalence are employed. Gideon Toury, in a pithy summation of this approach, has written that 'translations are facts of target cultures'. ${ }^{44}$ By approaching translation as a series of choices

44 Toury 1995: 29. 
made by historical actors for a variety of strategic reasons, we gain a greater appreciation for the agency of translators and for the performative nature of their work in specific times and places. Attention to the simultaneous mobilization of indigenous and foreign metaphors, the multivalency of Chinese characters, and the larger strategies behind individual translation decisions are critical to fully understanding the complicated social and cultural factors and considerations that went into the production and reception of Buddhist texts.

Here, I have explored one example of how reading a Buddhist translation against an analysis of translation tactics in the corpus as a whole can reveal that a seemingly 'erroneous' passage in fact is engaging in bicultural metaphorical wordplay in order to explain a foreign medical doctrine in an accessible way, while also drawing attention to Buddhism's superior efficacy in relieving suffering. Rather than focusing on the inaccuracy of the translation, investigating how and why the translator mixed his metaphors reveals both the ultimate meaning the text was intended to convey and the creativity of the individual involved in producing this translation.

\section{Bibliography}

Appiah, Kwame Anthony 1993, 'Thick Translation', Callaloo 16 (4): 808-19.

Bakhtin, Mikhail M. 1981, The Dialogic Imagination: Four Essays, translated by Michael Holquist, Austin: University of Texas Press.

Birnbaum, Raoul 1989a, 'Chinese Buddhist Traditions of Healing and the Life Cycle', in Lawrence E. Sullivan (ed.) Healing and Restoring: Health and Medicine in the World's Religious Traditions, London: Macmillan Publishing Company, 33-57.

1989b [1979], The Healing Buddha, Boulder, CO: Shambhala.

Black, Max 1954, 'Metaphor', Proceedings of the Aristotelian Society 55: 273-294.

1993 [1979], 'More on Metaphor', in Andrew Ortony (ed.), Metaphor and Thought, Cambridge: Cambridge University Press, 19-43.

Boucher, Daniel 1996, 'Buddhist Translation Procedures in Third-Century China: A Study of Dharmaraksa and his Translation Idiom', Ph.D. dissertation, University of Pennsylvania.

2008, Bodhisattvas of the Forest and the Formation of the Mahäyanna: A Study and Translation of the Rasstrapälapariprcch ā-Sutra, Honolulu: University of Hawai'i Press.

Chen Ming 陳明 2002, Yindu fanwen yidian 'Yili jinghua' yanjiu 印度梵文醫典《醫理精 華》研究, Beijing: Zhonghua shuju.

- 2005a, Dunhuang chutu huhua 'Qipo shu' yanjiu 敦煌出土胡話《耆婆書》研究 (English title: A Study on Sanskrit Text of Jivaka-pustaka from Dunhuang), Hong Kong: Xinwenfeng chuban gongsi.

2005b, 'Zhuan nü wei nan: Turning Female to Male, an Indian Influence on Chinese Gynaecology?', Asian Medicine: Tradition and Modernity 1 (2): 315-34.

2005c, Shufang yiyao: Chutu wenshu yu xiyu yixue 殊方異藥 : 出土文書與西域醫學

(English title: Foreign medicine in medieval China: Medical manuscripts discovered in Dunhuang and Western Regions), Beijing: Peking University Press. 
2006a, 'The Transmission of Indian Ayurvedic Doctrines in Medieval China: A Case Study of Aștānga and Tridoșa Fragments from the Silk Road', Annual Report of the International Research Institute for Advanced Buddhology at Soka University 9: 201-230.

__ 2006b, 'Hanyi mijiao wenxian zhong de shengming feituo chengfen bianxi-Yi tongzi fang he yanyaofang weili' 漢譯密教文獻中的生命吠陀成分辨析-以童子方和眼藥方為 例, Gujin lunheng 古今論衡 14: 28-46.

2007, 'The Transmission of Foreign Medicine via the Silk Roads in Medieval China: A Case Study of the Haiyao Bencao 海药本草', Asian Medicine 3 (2): 241-64.

Chen Shu-fen, 2004. 'On Xuanzang's transliterated version of the Sanskrit Prajn̄āpāramitährụdayasūtra (Heart Sutra)', Monumenta Serica 52: 113-59.

Cheung, Martha 2006, An Anthology of Chinese Discourse on Translation, Vol. 1: From Earliest Times to the Buddhist Project, Brooklands, Manchester, and Kinderhoek, N.Y.: St. Jerome.

Copp, Paul 2008, 'Notes on the Term "Dhāranī” in Medieval Chinese Buddhist Thought', Bulletin of the School of Oriental and African Studies, 71 (3): 493-508.

Demiéville, Paul 1937, 'Byō', in Sylvain Lévi et al. (eds.), Hōbōgirin 法寶義林: Dictionnaire encyclopédique du Bouddhisme d'après les sources chinoises et japonaises, Tokyo: Maison FrancoJaponaise, Vol. 3, 224-65.

1985, Buddhism and Healing: Demiéville’s Article 'Byö' from Höbögirin, translated by Mark Tatz, Lanham, Md.: University Press of America.

Deshpande, Vijaya 1999, 'Indian Influences on Early Chinese Ophthalmology: Glaucoma as a Case Study', Bulletin of the School of Oriental and African Studies 62 (2): 306-22.

— 2000, 'Ophthalmic Surgery: A Chapter in the History of Sino-Indian Medical Contacts', Bulletin of the School of Oriental and African Studies 63 (3): 370-88.

_ 2003-04, 'Nāgārjuna and Chinese Medicine', Studia Asiatica 4-5: 241-57.

2008, 'Glimpses of Āyurveda in Medieval Chinese Medicine', Indian Journal of History of Science 43 (2): 137-61.

Endo Jiro, et al. 1993a, 'Tan no kigen I’ 痰の起源 I, Nihon ishigaku zasshi 日本医史学雜誌 39

(3): $333-44$.

— 1993b, 'Tan no kigen II’ 痰の起源 II, Nihon ishigaku zasshi 日本医史学雜誌 39 (4): 543-53.

Even-Zohar, Itamar 1990, 'Polysystem Theory', Poetics Today 11 (1): 9-26.

1997, 'The Making of Culture Repertoire and the Role of Transfer', Target 9 (2): 355-63. 2004 [1978], 'The Position of Translated Literature Within the Literary Polysystem', in Lawrence Venuti (ed.), The Translation Studies Reader, London and New York: Routledge, 199-204.

Friedrich, Hugo 1992, 'On the art of translation', in Rainer Schulte and John Biguenet (eds.) Theories of Translation: An Anthology of Essays From Dryden to Derrida, Chicago: University of Chicago Press, 11-6.

Fukunaga Katsumi 福永勝美 1972, Bukkyō igaku shōsetsu佛教醫學詳說. Tokyo: Yüzankaku. 1990, Bukkyōigaku jiten 亿教医学事典. Tokyo: Yūzankaku.

Harrison, Paul 1997, 'The Ekottarikāgama Translations of An Shigao', in Petra Kieffer-Pülz and Jens-Uwe Hartmann (eds.), Bauddhavidyäsudhäkarah: Studies in Honour of Heinz Bechert on the Occasion of His 65th Birthday, Swisttal-Odendorf: Indica et Tibetica Verlag, 261-84.

Hsu, Elisabeth 2007, 'The Experience of Wind in Early and Medieval Chinese Medicine,' Journal of the Royal Anthropological Institute N.S. 13 (Supplement 1): 117-34.

Jakobson, Roman 2004 [1959], 'On Linguistic Aspects of Translation,' in Lawrence Venuti (ed.), The Translation Studies Reader, London and New York: Routledge, 138-43.

Kuriyama, Shigehisa 1994, 'The Imagination of Winds and the Development of the Chinese Conception of the Body,' in Angela Zito and Tani E. Barlow (eds.), Body, Subject and Power in China, Chicago: University of Chicago Press, 23-41. 
Lefevere, André 1992, Translation, Rewriting, and the Manipulation of Literary Frame, Routledge: London.

Long Baijian龙伯坚 and Long Shizhao 龙式昭 2006, Huangdi neijing jijie: suwen 黄帝内经集 解 : 素问. Tianjin: Tianjin kexue jishu chubanshe 天津科学技术出版社.

Mair, Victor H. 2010, 'What is Geyi After All?', in Alan K. L. Chan and Yuet-Keung Lo (eds.), Philosophy and Religion in Early Medieval China, Albany: SUNY Press, 227-64.

Mazars, Sylvain 2008, Le bouddhisme et la medecine traditionelle de l'Inde, Paris: Springer.

Meulenbeld, G. Jan 1991, 'The Constraints of Theory in the Evolution of Nosological Classifications: A Study on the Position of Blood in Indian Medicine (Ayurevda)', in G. Jan Meulenbeld (ed.), Medical Literature From India, Sri Lanka and Tibet, Leiden: E.J. Brill, $91-106$

— 1992, 'The Characteristics of a Dosa', Journal of the European Ayurvedic Society, 2: 1-5. 2009, 'Some Neglected Aspects of Ayurveda, or the Illusion of a Consistent Theory', in Dominik Wujastyk (ed.), Mathematics and Medicine in Sanskrit, Delhi: Motilal Banarsidass, $105-17$.

Mitchell, Craig et al. 1999, Shang Han Lun: On Cold Damage, Brookline, Mass.: Paradigm Publications.

Mitra, Jyotir 1985, A Critical Appraisal of Ayurvedic Material in Buddhist Literature with Special Reference to Tripitaka, Varanasi: Jyotiralok Prakashan.

Mollier, Christine 2008, Buddhism and Taoism Face to Face: Scripture, Ritual, and Iconographic Exchange in Medieval China, Honolulu: University of Hawai'i Press.

Nattier, Jan 2008, A Guide to the Earliest Chinese Buddhist Translations: Texts from the Eastern Han 東漢 and Three Kingdoms 三國 Periods, Tokyo: International Research Institute for Advanced Buddhology, Soka University.

Nihonyanagi Kenji 二本柳賢司 1994, Bukkyō igaku gaiyo 佛教醫學概要. Kyoto: Hozokan.

Obinata Daijō 大日方大乗 1965, Bukkyō igaku no kenkyū 仏教医学の研究. Tokyo: Kazama Shobō.

Orzech, Charles D. 2002, 'Fang Yankou and Pudu: Translation, Metaphor, and Religious Identity', in Livia Kohn and Harold D. Roth (eds.), Daoist Identity: History, Lineage, and Ritual, Honolulu: University of Hawai'i Press, 213-34.

_ 2002-03, 'Metaphor, Translation, and the Construction of Kingship in the Scripture for Humane Kings and the Mahämāyùrū Vidyāräjn̄in Sütra', Cahiers d'Extrême-Asie, 13: 55-83.

Pym, Anthony, Miriam Shelsinger, and Zuzana Jettmarová (eds.) 2006, Sociocultural Aspects of Translating and Interpreting, Amsterdam and Philadelphia: Benjamins.

Salguero, C. Pierce 2009, 'The Buddhist Medicine King in Literary Context: Reconsidering an Early Medieval Example of Indian influence on Chinese Medicine and Surgery', History of Religions 48 (3): 183-210.

_ 2010, "A Flock of Ghosts Bursting Forth and Scattering": Healing Narratives in a SixthCentury Chinese Buddhist Hagiography,' East Asian Science Technology \& Medicine (EASTM) 32: 89-120.

Scharfe, Hartmut 1999, 'The Doctrine of the Three Humors in Traditional Indian Medicine and the Alleged Antiquity of Tamil Siddha Medicine', Journal of the American Oriental Society, 119 (4): 609-629.

Snell-Hornby, Mary 1995 [1988], Translation Studies: An Integrated Approach, Amsterdam and Philadelphia: Benjamins.

Stewart, Tony K. 2001, 'In Search of Equivalence: Conceiving Muslim-Hindu Encounter Through Translation Theory', History of Religions, 40 (3): 260-87.

Strickmann, Michel 2002, Chinese Magical Medicine, Stanford: Stanford University Press.

Toury, Gideon 1995, Descriptive Translation Studies and Beyond, Amsterdam and Philadelphia: Benjamins. 
Unschuld, Paul U. 1979, 'The Chinese Reception of Indian Medicine in the First Millennium A.D.', Bulletin of the History of Medicine, 53 (3): 329-45.

2010 [1985], Medicine in China: A History of Ideas, Berkeley: University of California Press.

Vetter, Tilmann and Paul Harrison 1998, 'An Shigao's Chinese translation of the Saptasthänasütra', in Paul Harrison and Gregory Schopen (eds.), Süryacandrāya: Essays in Honour of Akira Yuyama on the Occasion of His 65th Birthday, Swisttal-Odendorf: Indica et Tibetica Verlag, 197-216.

Watson, Burton 1997, The Vimalakirti Sutra, New York: Columbia University Press.

Zysk, Kenneth G. 1993, 'The Science of Respiration and the Doctrine of the Bodily Winds in Ancient India,' Journal of the American Oriental Society 113 (2): 198-213.

2000 [1991], Asceticism and Healing in Ancient India: Medicine in the Buddhist Monastery, New Delhi: Motilal Banarsidass.

_ 2007, 'The Bodily Winds in Ancient India Revisited,' Journal of the Royal Anthropological Institute N.S. 13 (Supplement 1): 105-15. 